\title{
DETERMINANTS AFFECTING PURCHASE INTENTION OF HALAL PRODUCTS: AN ARTICLE REVIEW
}

\author{
FAKTOR-FAKTOR YANG MEMPENGARUHI MINAT BELI \\ PRODUK HALAL: ULASAN
}

Received: 15/10/2020; Revised: 15/11/2020; Accepted:28/11/2020; Published: 30/11/2020

Fitry Oktavia Fatmi, Anis Najiha Ahmad, Betania Kartika

International Institute for Halal Research Training

International Islamic University Malaysia

*Corresponding author: fitry.oktavia@gmail.com

\begin{abstract}
This study's main objectives are to analyze the literature related to the factors influencing halal products' purchase intention and identify the literature gap for future study recommendations. The researchers evaluate the numerous assessed studies conducted in different countries. Halal products' major determinants in purchase intention are attitude, subjective norm, perceived behaviour control, religiosity, halal awareness, and halal certification. The researchers found few studies that examined factors such as price, exposure, place, halal supply chain, and advertising in their studies. Common theories used in previous literature are the Theory of Planned Behavior (TPB). One of the gaps for further research on halal products' purchase intention is the lack of research in the halal pharmaceutical, halal fashion, halal tourism, halal supply chain, and halal finance fields. In the future, the researcher may apply other theories that can be used to study purchase intention, such as theory consumption value or theory diffusion of innovation.
\end{abstract}

Keywords: Halal Products, Halal, Purchase Intention Determinants

\begin{abstract}
ABSTRAK
Tujuan utama penelitian ini adalah untuk melakukan analisis kepustakaan terkait faktor-faktor yang mempengaruhi minat beli produk halal dan mengidentifikasi kesenjangan pustaka agar dapat memberikan rekomendasi pada penelitian selanjutnya. Para peneliti mengevaluasi beragam studi yang telah dilakukan di berbagai negara. Penentu utama produk halal dalam minat beli adalah sikap, norma subjektif, persepsi kontrol perilaku, religiusitas, kesadaran halal, dan sertifikasi halal. Ditemukan beberapa penelitian yang mempelajari faktor-faktor seperti harga, keterpaparan, tempat, rantai pasokan halal, dan periklanan dalam studi mereka. Teori yang umum digunakan dalam penelitian sebelumnya adalah Theory of Planned Behavior (TPB). Salah satu kesenjangan penelitian yang perlu dipertimbangkan untuk penelitian minat beli produk halal di masa mendatang adalah kurangnya penelitian di bidang farmasi halal, fashion halal, wisata halal, rantai pasok halal, dan keuangan halal. Pada studi selanjutnya, peneliti dapat menerapkan teori lain untuk mempelajari minat beli, seperti teori nilai konsumsi atau teori difusi inovasi.
\end{abstract}

Kata kunci: Produk halal, halal, faktor-faktor penentu minat beli

How to cite: Fatmi FO, Ahmad AN, Kartika B. 2020. Determinants Affecting Purchase Intention of Halal Products: an Article Review. Journal of Halal Product and Research. 3(2), 63-79, https://dx.doi.org/10.20473/jhpr.vol.3-issue.2.63-79. 


\section{INTRODUCTION}

Nowadays, almost one-third of the world's inhabitants are Muslims. This number is increasing at $1.84 \%$, from 2.14 billion in 2018 to 2.25 billion in 2019 (Population, 2020). The rapid growth of the Muslim population worldwide is the fundamental cause of the global halal industry's expansion. To elucidate, Halal means lawful or allowed. Halal products are products prepared following Islamic law, alsoknown as Sharia law or Islamic law, in compliance with acceptable processes or procedures (Nur Famiza et al., 2017). Halal's theory is based on the Quran (Muslim Holy Book) and Sunnah (Prophet Muhammad's normal practices). Halal products are widely used for food, meat, cosmetics, personal care products, pharmaceutical, food ingredients, and contact with food materials (ICV, 2019). As a Muslim, consumption of Halal products is an obligation, as stated in the Qur'an,

"And eat the lawful and good food (thayib) from that which has been granted to you and fear Allah and believe in Him" (Al Maidah 5: 88).

The Halal markets, especially food, have received positive responses because their qualities have covered the fundamental aspects of hygiene, safety, health, and quality. Thomson Reuters (2020) stated that the global Muslim spending across lifestyle industries as follows, the Islamic finance industry has US\$2.88 trillion in total assets. Food and beverage lead Muslim spending by segment to US\$ 1.17 trillion. Apparel and clothes to US\$ 277 billion, media and entertainment to US\$222 billion, travel to US\$194 billion, and pharmaceutical and cosmetics to US\$ 94 billion and US\$ 66 billion, respectively. The Halal market is expected to continue growing in the coming years.

Given that Halal products' demand is expected to increase in the coming years, the determinants affecting purchase intention towards Halal products need to be studied to facilitate market growth. The purpose of this review article is twofold: first, to analyze the factors influencing halal products' purchase intention, and second, identifies literature gap for future studies recommendations. The findings could become inputs to the Halal manufacturers to recognize and target the Halal products' consumers, understand their outlook, and the factors that influence their intention in purchasing halal products. This study focuses on the purchase intention of multiple Halal products such as foods, meat, cosmetics, pharmaceutical, finance, tourism, and fashion sectors. Identification of gaps in the literature could also expedite the research and development of the Halal field.

\section{METHODOLOGY}

The approach used by Joshi \& Rahman( 2015) is adapted to achieve the objectives of the article. The approach used for this review article is as follows.

\section{Scope}

This study analyses the empirical research on consumer Halal purchase intention papers published in Scopus. It focuses only on studies that sought to identify and test the various factors affecting Halal purchase intention. Studies are obtained through an electronic search of the Scopus database. The Scopus database is selected to ensure that only high-quality research is included. Scopus database one of the largest bibliographic databases of peer-reviewed articles (Haleem et al., 2020).

\section{Selection of Articles}

Selection criteria Halal purchasing purpose requires a wide variety of consumption activities. This paper focuses only on studies that illustrate the various factors influencing consumers' intention to buy halal related products or services. The following selection criteria are adopted to select the related studies: (1) The article should be a research article (2) The research should address factors influencing the purchasing intention related to halal sectors.

\section{Selection Process}

Research papers are found through a systematic search method that includes searching for keywords in the title, abstract, and keyword portion of the Scopus database. The keyword used is "Halal Purchase Intention." The search resulted in 88 articles. In the next step, the papers' content is reviewed by cross- checking the abstracts to ensure that the database contained only the correct articles for analysis, just empirical research exploring different factors influencing customers' purchasing intention. The process contributed to the deletion of 43 articles. Next, all the papers are reviewed for replication, and one article is found to be duplicated. After the elimination process, 44 eligible papers are left for the final review. 
The selected articles are limited in number since only empirical articles related to the Halal purchase intention are included.

\section{Analysis Approach}

Full-text research articles have been extracted from the Scopus database. The entire content of a particular study is examined. It includes analysis and review of title, literature, conceptual background, methodology, results, discussions, implications, and future research directions. Table 1 shows the list of studies affecting halal purchase intention reviewed in this article.

Table 1. List of studies affecting halal purchase intention

\begin{tabular}{|c|c|c|c|c|}
\hline No & Year & Authors & Methods & $\begin{array}{l}\text { Number of } \\
\text { Samples }\end{array}$ \\
\hline 1 & 2011 & (Said et al., 2011) & Quantitative & 264 \\
\hline 2 & 2013 & (Aziz \& Chok, 2013) & Quantitative & 226 \\
\hline 3 & 2013 & $\begin{array}{l}\text { (Hussin, Hashim, Yusof, } \\
\text { \& Alias, 2013) }\end{array}$ & Quantitative & 200 \\
\hline 4 & 2015 & (Adura Mohd Yusoff et al., 2015) & Quantitative & 304 \\
\hline 5 & 2015 & (Pool \& Najafabadi, 2015) & Quantitative & 864 \\
\hline 6 & 2016 & (Azam, 2016) & Quantitative & 210 \\
\hline 8 & 2017 & (Ali et al., 2017) & Quantitative & 2931 \\
\hline 7 & 2017 & (Soon \& Wallace, 2017) & Quantitative & 324 \\
\hline 9 & 2017 & (Muhamed et al., 2017) & Quantitative & $\begin{array}{l}\text { Not stated in } \\
\text { the article }\end{array}$ \\
\hline 10 & 2017 & (Abu-Hussin et al., 2017) & Quantitative & 332 \\
\hline 11 & 2017 & (Ya et al., 2017) & Quantitative & 201 \\
\hline 12 & 2017 & $\begin{array}{l}\text { (Afzaal Ali Guo Xiaoling Mehkar } \\
\text { Sherwani Adnan Ali, 2017) }\end{array}$ & Quantitative & 436 \\
\hline 13 & 2018 & (Elseidi, 2018) & Quantitative & 400 \\
\hline 14 & 2018 & (Fatema et al., 2018) & Quantitative & 200 \\
\hline 15 & 2018 & (Garg \& Joshi, 2018) & Quantitative & 288 \\
\hline 16 & 2018 & (Mohd Suki \& Abang Salleh, 2018) & Quantitative & 480 \\
\hline 17 & 2018 & (Putri \& Abdinagoro, 2018) & Quantitative & 100 \\
\hline 18 & 2018 & (Syukur \& Nimsai, 2018) & Quantitative & 480 \\
\hline 19 & 2018 & (Ali et al., 2018) & Quantitative & 347 \\
\hline 20 & 2018 & (Adnan Ali et al., 2018) & Quantitative & 378 \\
\hline 21 & 2019 & (Bashir, 2019) & Quantitative & 230 \\
\hline 22 & 2019 & (Memon et al., 2019) & Quantitative & 250 \\
\hline 23 & 2019 & (Arbak et al., 2019) & Mixed-Method & 110 \\
\hline 24 & 2019 & (Khan et al., 2019) & Quantitative & 350 \\
\hline 25 & 2019 & (Marmaya et al., 2019) & Quantitative & 110 \\
\hline 26 & 2019 & (Nurzulain et al., 2019) & Quantitative & 63 \\
\hline 27 & 2019 & (Pasha et al., 2019) & Quantitative & 192 \\
\hline 28 & 2019 & $\begin{array}{c}\text { (Abdalla M. Bashir, Bayat, Olutuase, \& } \\
\text { Abdul Latiff, 2019) }\end{array}$ & Quantitative & 230 \\
\hline 29 & 2019 & (Pradana et al., 2019) & Quantitative & 215 \\
\hline 30 & 2019 & (Nurhayati \& Hendar, 2019) & Quantitative & 238 \\
\hline 31 & 2020 & (Bukhari et al., 2020) & Quantitative & 378 \\
\hline 32 & 2020 & (Afzaal Ali et al., 2020) & Quantitative & 481 \\
\hline 33 & 2020 & (Aslinda Jamil, Atifah Fakhriyah, 2020) & Quantitative & 318 \\
\hline 34 & 2020 & (Bhatti et al., 2020) & Quantitative & 140 \\
\hline
\end{tabular}




\begin{tabular}{ccccc}
\hline No & Year & Authors & Methods & $\begin{array}{c}\text { Number of } \\
\text { Samples }\end{array}$ \\
\hline Continuance & & Table 2 List of studies affecting halal purchase intention & \\
\hline 35 & 2020 & (Hassan et al., 2020) & Quantitative & 152 \\
\hline 36 & 2020 & (M. Pradana et al., 2020) & Quantitative & 500 \\
\hline 37 & 2020 & (N. Khan et al., 2020) & Quantitative & 262 \\
\hline 38 & 2020 & (Pradana et al., 2020b) & Quantitative & 228 \\
\hline 39 & 2020 & (Pradana, Wardhana, et al., 2020) & Quantitative & 500 \\
\hline 40 & 2020 & (Shaari et al., 2020) & Quantitative & 760 \\
\hline 41 & 2020 & (Suparno, 2020) & Quantitative & 201 \\
\hline 42 & 2020 & (Ustaahmetoğlu, 2020) & Quantitative & Not stated in \\
& & & & Quantitative \\
\hline 43 & 2020 & (Pradana et al., 2020) & 500 \\
\hline 44 & 2020 & (Hamzah et al., 2020) & Quantitative & 373 \\
\hline
\end{tabular}

\section{RESULT}

\section{Overview of the Previous Study}

The review of previous studies of purchase intention towards Halal products had led to 44 articles; 23 papers focused on Halal food, seven articles emphasized cosmetics, three articles studied Halal meat, six investigated Halal products, two studied Halal finance, one researched Halal pharmaceutical, one article focused on the Muslim made products. One article is on the retail store (see Table 2).

Table 3. List of papers halal studies by-sectors

\begin{tabular}{|c|c|c|c|}
\hline No & Scopes & $\begin{array}{l}\text { Number of } \\
\text { Articles }\end{array}$ & Authors \\
\hline 1 & Food & 23 & $\begin{array}{l}\text { (Afzaal Ali et al., 2017, 2018, 2020; Azam, 2016; Abdalla } \\
\text { M. Bashir et al., 2019; Abdalla Mohamed Bashir, 2019; } \\
\text { Elseidi, 2018; Hamzah et al., 2020; A. Khan et al., 2019; } \\
\text { Marmaya et al., 2019; Nurzulain et al., 2019; M. Pradana } \\
\text { et al., 2020; Mahir Pradana et al., 2019; Mahir Pradana, } \\
\text { Huertas-García, et al.., 2020b, 2020a; Mahir Pradana, } \\
\text { Wardhana, et al., 2020; Said et al., 2011; Shaari et al., } \\
\text { 2020; Soon \& Wallace, 2017; Syukur \& Nimsai, 2018; } \\
\text { Ustaahmetoğlu, 2020; Ya et al., 2017) }\end{array}$ \\
\hline 2 & $\begin{array}{l}\text { Cosmetic and } \\
\text { Personal Care }\end{array}$ & 7 & $\begin{array}{l}\text { (Arbak et al., 2019; Aslinda Jamil, Atifah Fakhriyah, 2020; } \\
\text { Garg \& Joshi, 2018; Siti Rahayu Hussin, 2013; N. Khan et } \\
\text { al., 2020; Putri \& Abdinagoro, 2018; Suparno, 2020) }\end{array}$ \\
\hline 3 & Meat & 3 & $\begin{array}{l}\text { (Afzaal Ali, Gua Xiaoling, Mehkar Sherwani, 2017; Adnan } \\
\text { Ali et al., 2018; Bhatti et al., 2020) }\end{array}$ \\
\hline 4 & Pharmaceutical & 1 & (Bukhari et al., 2020) \\
\hline 5 & Halal Products & 6 & $\begin{array}{l}\text { (Abu-Hussin et al., 2017; Aziz \& Chok, 2013; Memon et } \\
\text { al., 2019; Nurhayati \& Hendar, 2019; Pool \& Najafabadi, } \\
\text { 2015; Ya et al., 2017) }\end{array}$ \\
\hline 6 & Finance & 2 & (Fatema et al., 2018; Muhamed et al., 2017) \\
\hline 7 & $\begin{array}{l}\text { Muslim Made } \\
\text { Products }\end{array}$ & 1 & (Hassan et al., 2020) \\
\hline 8 & Retail Store & 1 & (Mohd Suki \& Abang Salleh, 2018) \\
\hline
\end{tabular}




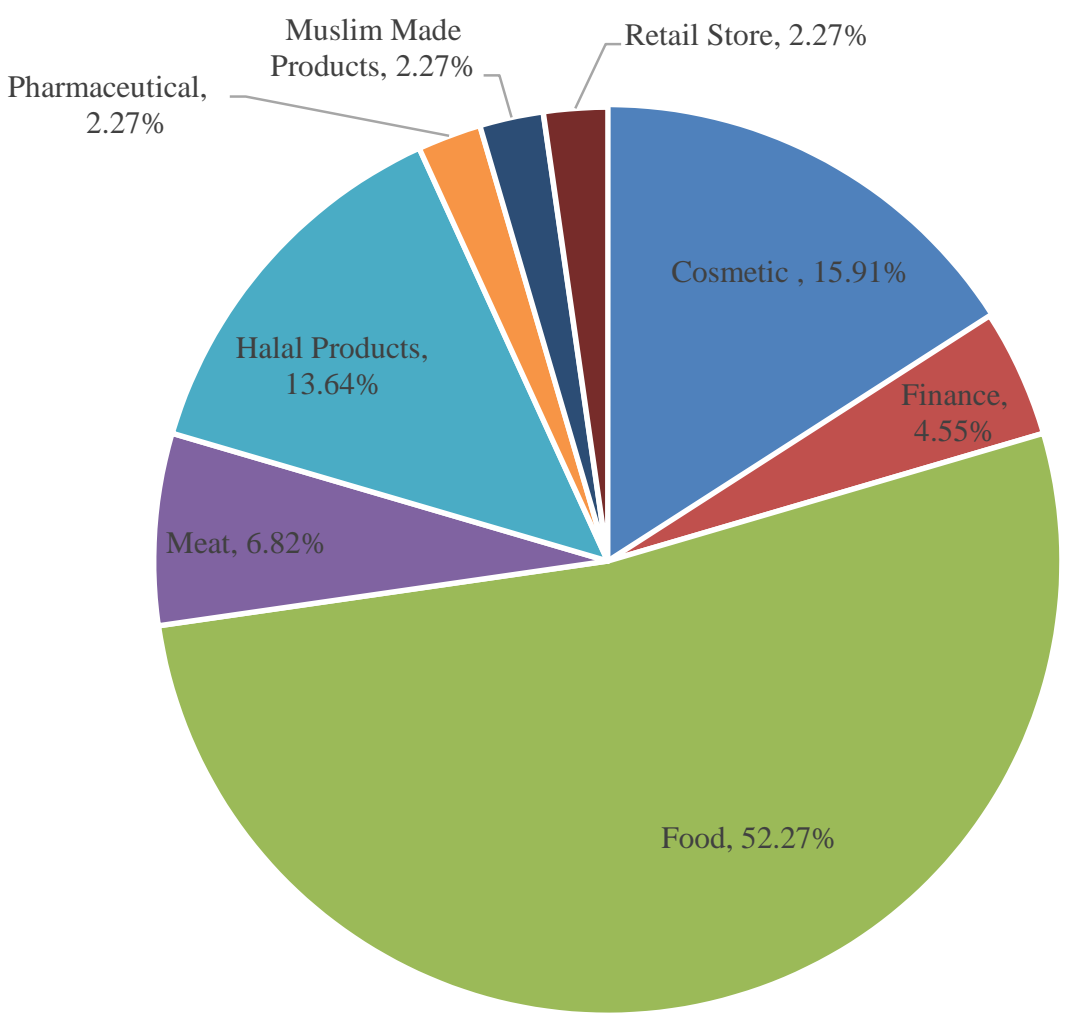

Figure 1. The Percentages of purchase intention halal products articles by sectors

Figure 1 further summarizes and illustrates the percentage of the article based on sectors. The findings indicate Halal foods have been extensively studied compared to other sectors or scopes. Halal foods have topped the chart with $52,27 \%$, followed by cosmetic articles with $15,91 \%$, Halal products with $13,64 \%$, Halal meat with $6.82 \%$, finance $4,55 \%$ and pharmaceutical, retail store, Muslim made products with $2,27 \%$ respectively. The previous researchers used quantitative methods by using questionnaires to test their hypotheses about the relationship between the factors affecting purchase intention towards Halal products. However, only one study conducted by Arbak et al. (2019) used a mixed-method, questionnaires, and interviews with the respondents. The respondents' numbers ranged from 63 respondents (Nurzulain et al., 2019) to 2931 respondents (Soon \& Wallace, 2017).

Overall, majorities of studies of purchase intention were conducted by Malaysian researchers with the highest number of 15 articles, followed by China's researchers with five articles. At the same time, Indonesia and Spain produced four papers. Authors from countries such as the United Kingdom, Pakistan, and South Africa have published two related articles. In contrast, authors from Thailand, Turkey, Singapore, Saudi Arabia, Iran, and India published one article related to Halal products' purchasing intention. Researchers from Malaysia collaborated with others from Thailand and Pakistan to study purchase intention in halal products and produced one article for each collaboration. The list of articles published based on the country is shown in Table 3. 
Table 4. The Articles' List of Halal Products, Purchase Intention by Country of Survey

\begin{tabular}{|c|c|c|c|c|c|c|c|c|c|c|c|}
\hline \multirow[b]{2}{*}{ Countries } & \multirow[b]{2}{*}{$\begin{array}{l}\text { Number } \\
\text { of Articles }\end{array}$} & \multirow[b]{2}{*}{$\%$} & \multirow[b]{2}{*}{ Authors } & \multicolumn{8}{|c|}{ Scope of Halal Products } \\
\hline & & & & Food & Meat & $\begin{array}{l}\text { Cosmetic/ } \\
\text { Personal Care }\end{array}$ & $\begin{array}{l}\text { Pharma } \\
\text { ceutical }\end{array}$ & $\begin{array}{l}\text { Halal } \\
\text { Product }\end{array}$ & $\begin{array}{l}\text { Halal } \\
\text { Flnance }\end{array}$ & $\begin{array}{l}\text { Muslim Made } \\
\text { Products }\end{array}$ & $\begin{array}{l}\text { Retail } \\
\text { Store }\end{array}$ \\
\hline Bangladesh & 1 & & (Fatema et al., 2018) & - & - & - & - & - & 1 & - & - \\
\hline China & 5 & 11.63 & $\begin{array}{l}\text { (Afzaal Ali, Gua Xiaoling, Mehkar Sherwani, 2017; Afzaal Ali et } \\
\text { al., 2017, 2018) }\end{array}$ & 3 & 2 & - & - & - & - & - & - \\
\hline India & 1 & 2.33 & (Garg \& Joshi, 2018) & - & - & 1 & - & - & - & - & - \\
\hline Indonesia & 4 & 9.30 & $\begin{array}{l}\text { (Nurhayati \& Hendar, 2019; Mahir Pradana et al., 2019; Putri \& } \\
\text { Abdinagoro, 2018; Suparno, 2020) }\end{array}$ & 1 & -- & 2 & - & 1 & - & - & - \\
\hline Iran & 1 & 2.33 & (Pool \& Najafabadi, 2015) & & & & & 1 & & & \\
\hline Malaysia & 15 & 32.56 & $\begin{array}{l}\text { (Adura Mohd Yusoff et al., 2015; Arbak et al., 2019; Aslinda } \\
\text { Jamil, Atifah Fakhriyah, 2020; Aziz \& Chok, 2013; Hamzah et al., } \\
\text { 2020; Hassan et al., 2020; S. R. Hussin et al., 2013; A. Khan et } \\
\text { al., 2019; N. Khan et al., 2020; Marmaya et al., 2019; Mohd Suki } \\
\text { \& Abang Salleh, 2018; Muhamed et al., 2017; Nurzulain et al., } \\
\text { 2019; Said et al., 2011; Ya et al., 2017) }\end{array}$ & 6 & - & 4 & - & 2 & 1 & 1 & 1 \\
\hline Malaysia dan Pakistan & 1 & 2.33 & (Bukhari et al., 2020) & - & - & - & 1 & - & - & - & - \\
\hline Norway & 1 & 2.33 & (Bhatti et al., 2020) & - & 1 & - & - & & - & - & - \\
\hline Pakistan & 2 & 4,65 & (Memon et al., 2019; Pasha et al., 2019) & 1 & - & - & - & 1 & - & - & - \\
\hline Saudi Arabia & 1 & 2.33 & (Azam, 2016) & 1 & - & - & - & - & - & - & - \\
\hline Singapore & 1 & 2.33 & (Abu-Hussin et al., 2017) & - & - & - & - & 1 & - & - & - \\
\hline South Africa & 2 & 4,65 & (Abdalla M. Bashir et al., 2019; Abdalla Mohamed Bashir, 2019) & 2 & - & - & - & - & - & - & - \\
\hline Spain & 4 & 9.30 & $\begin{array}{l}\text { (M. Pradana et al., 2020; Mahir Pradana, Huertas-García, et al., } \\
\text { 2020a, 2020b; Mahir Pradana, Wardhana, et al., 2020) }\end{array}$ & 4 & - & - & - & - & - & - & - \\
\hline Thailand & 1 & 2.33 & (Syukur \& Nimsai, 2018) & 1 & - & - & - & - & - & - & - \\
\hline Thailand and Malaysia & 1 & 2.33 & (Adura Mohd Yusoff et al., 2015) & 1 & - & - & - & - & - & - & - \\
\hline Turkey & 1 & 2.33 & (Ustaahmetoğlu, 2020) & 1 & - & - & - & - & - & - & - \\
\hline United Kingdom & 2 & 4,65 & (Elseidi, 2018; Soon \& Wallace, 2017) & 2 & & & & & & & \\
\hline
\end{tabular}




\section{Theory Used}

This article also reviews the theory used in previous research. Bray (2000) stated that in the past 300 years ago, a few economists led by Nicholas Bernoulli, John von Neumann, and Oskar Morgenstern studied the subject of consumer decision-making, for which they had begun to examine the basis of consumer decision-making. Studies on consumer behaviour have been continued, and several improvements have been established. The theory in consumer decision-making could help us predict the intentions and actions concerning the purchase or use of a particular brand or product and even choose between different brands or products (Arifani \& Haryanto, 2018). The previous articles reviewed have employed several theories, such as the Theory of Planned Behaviour (TPB) and Extended TPB, to examine the relationship between the factors influencing halal products' purchasing intention. Other studies, however, did not use any theory as a basis of their determinants.

Theory Planned Behaviour (TPB) is the extension of the Theory of Reason Action (TRA). TRA was established in the 1960s to explain variation in consumer behaviour (Ajzen, 2011). It is useful in multiple studies. TRA consisted of attitudes and subjective norms. In 1985, Ajzen extended the TRA by adding the perceived behavioural control to improve the TRA's predictive power. This extended theory is known as Theory Planned Behaviour (TPB) (Ajzen, 1991). TPB has become one of the most widely cited and influential models for predicting human social behaviour. The core concept of TPB is that people systematically use knowledge before taking action and that their behaviour actions are not taken impulsively.

TPB proposed that behaviour intention is a feature of three aspects: attitude, subjective norms, and perceived behaviour control, and is the most proximal determinant of behaviour impact. The first indicator is the attitude towards behaviour and refers to the degree to which an individual has a favourable or unfavourable assessment or assessment of the behaviour in question. The second indicator is a social factor referred to as a subjective norm; it relates to perceived social pressure to perform or not perform a particular behaviour. The third indicator refers to the perceived behaviour control or difficulty of conducting behaviour, representing experience and expected challenges and obstacles. These motives may account for a substantial proportion of behavioural variance (Ajzen, 2012).

TPB is considered to be one of the most influential theories in the field of social psychology. Even though TPB is an influential theory in social psychology, this theory can also be applied in many contexts because it offers a valuable philosophical structure for coping with human behaviour. It has been used to predict and understand the actions of individuals in various contexts such as purchase intention in the green product (Paul et al., 2016), internet banking (Shih, 2004), organic personal care products (Kim et al., 2011), reuseable shopping bag (Arifani \& Haryanto, 2018), halal products (Memon et al., 2019), halal meat consumption (Afzaal Ali, Gua Xiaoling, Mehkar Sherwani, 2017) and Halal food consumption (Syukur \& Nimsai, 2018).

Some researchers also tested TPB to assess people's intention to buy by combining TPB factors with variables other than those described above (attitude, social norms, and perceived behavioral control). This hybrid theory is known as extended TPB. Other factors that are relevant to the purchase of halal products and often tested as extended TPB are religiosity (Afzaal Ali, Gua Xiaoling, Mehkar Sherwani, 2017; Bukhari et al., 2020; Garg \& Joshi, 2018; A. Khan et al., 2019; Memon et al., 2019), halal certification (Nurzulain et al., 2019), awareness (Abdalla M. Bashir et al., 2019), knowledge (A. Khan et al., 2019; Mohd Suki \& Abang Salleh, 2018) and others factors such as trust, self-efficacy, motivation.

Approximately eight papers had analyzed TPB factors, in line with eight articles that examined the theory of extended TPB. About 28 journals article used various determinants without using any particular theory to test the hypothesis between influence factors and halal products' purchase intention. Examples of the determinants used are Halal awareness, religiosity, Halal certification/Halal logo, brand, safety, price, health, ingredients, promotion, quality, advertisement, knowledge, motivation, trust, exposure, and advertising. 


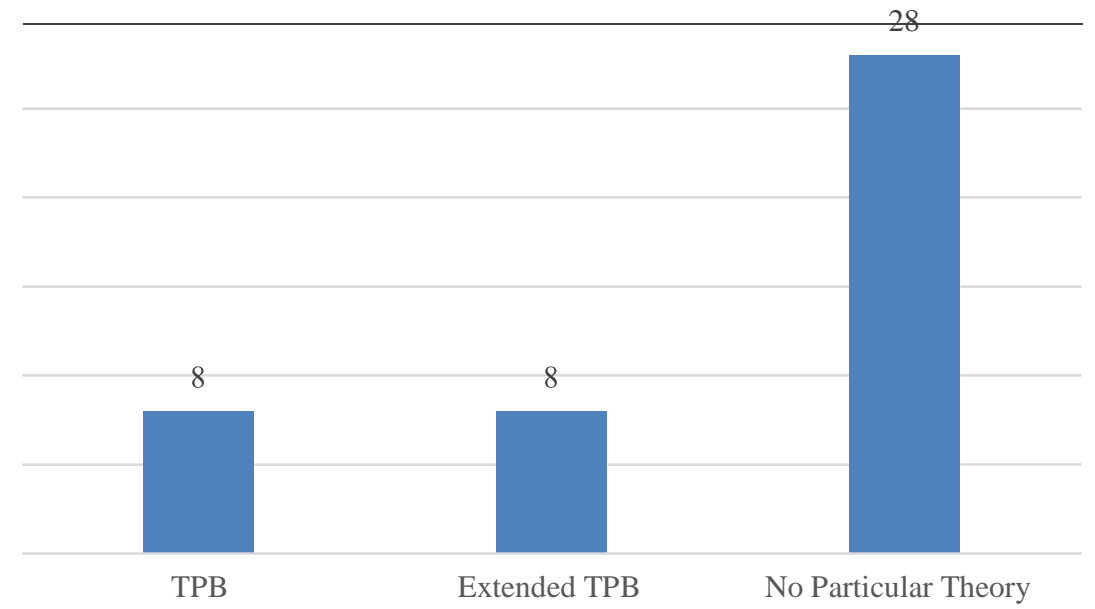

Figure 2. Theories of Purchase Intention Used in Studies of Halal Products

\section{Determinants/Factors Affecting Halal Products Purchase Intention}

A systematic analysis of 44 articles related to consumer Halal Purchase Intent identified many factors. A detailed list of all variables affecting Halal purchase intention is given in Table 4 . In the first column, the authors identify the various factors influencing the customer halal's purchasing intention, followed by the direction of effect in the next column. The last two columns show: 1) individual studies (as shown in Table 1) that report a specific factor, and 2) the total number of such studies.

Table 5 Determinants affecting halal purchase intention

\begin{tabular}{llll}
\hline Determinants & Directions & Studies & $\begin{array}{l}\text { Total Number of } \\
\text { Studies }\end{array}$ \\
\hline TPB & & & 21 \\
\hline- Attitude & + & $6,7,9,10,12,13,14,15,16$, & \\
& & $20,21,22,24,26,27,28,35,36,38,39,41$, & \\
& - & 25,31 & 2 \\
\hline - Subjective Norm & + & $8,9,10,12,13,15,16,20,24,25,26$, & 13 \\
\hline & - & 29,36, & 5 \\
\hline $\begin{array}{l}\text { Perceived } \\
\text { Behaviour Control }\end{array}$ & + & $7,9,10,12,13,15,16,18,20,22,24,25,26$, & 15 \\
\hline & - & 29,35 & \\
\hline $\begin{array}{l}\text { Halal Awareness / } \\
\text { Halal } \\
\text { Consciousness }\end{array}$ & + & 28,31 & 2 \\
\hline $\begin{array}{l}\text { Religiosity/Belief/ } \\
\text { Credence }\end{array}$ & + & $2,6,14,21,27,28,29,30,33,35,40$ & 11 \\
\hline & & $6,11,12,15,18,24,27,29,30,31,33,37,38$, & 14 \\
\hline $\begin{array}{l}\text { Halal Logo / Halal } \\
\text { Certification }\end{array}$ & + & 17 & 1 \\
\hline & - & $2,6,16,17,21,26,33,37,44$ & 9 \\
\hline
\end{tabular}




\begin{tabular}{|c|c|c|c|}
\hline Determinants & Directions & Studies & $\begin{array}{l}\text { Total Number of } \\
\text { Studies }\end{array}$ \\
\hline Continuance & \multicolumn{3}{|c|}{ Table 6 Determinants affecting halal purchase intention } \\
\hline Beauty Blogger & - & 17 & 1 \\
\hline Arabic Brand Name & - & 17 & 1 \\
\hline \multirow{2}{*}{$\begin{array}{l}\text { Brand components } \\
\text { (brand love, brand } \\
\text { personality, brand } \\
\text { image, brand } \\
\text { characteristic, and } \\
\text { brand satisfaction) }\end{array}$} & + & $2,5,6,14,18,23,32$ & 7 \\
\hline & - & 3,8 & 2 \\
\hline $\begin{array}{l}\text { Word of Mouth } \\
\text { (WOM) }\end{array}$ & - & 5,44 & 2 \\
\hline Halal Knowledge & + & 24,30 & 2 \\
\hline Trust & + & $8,12,14,20,32$ & 5 \\
\hline Motivational & + & 12 & 1 \\
\hline Self-Efficacy & + & 24 & 1 \\
\hline Self-Identity & + & 20 & 1 \\
\hline Moral Obligation & + & 20 & 1 \\
\hline Influences & + & 36 & 1 \\
\hline Exposure & + & 6 & 1 \\
\hline \multirow[t]{2}{*}{ Price } & + & 3,34 & 2 \\
\hline & - & 18 & 1 \\
\hline Ingredients & + & 3,37 & 2 \\
\hline \multirow{2}{*}{$\begin{array}{l}\text { Promotional } \\
\text { Influence }\end{array}$} & + & 2,37 & 2 \\
\hline & - & 18 & 1 \\
\hline Safety & + & 13 & 1 \\
\hline \multirow{2}{*}{$\begin{array}{l}\text { Religious Messages } \\
\text { on Adv }\end{array}$} & + food & 42 & 1 \\
\hline & - bank loan & 42 & 1 \\
\hline \multirow{2}{*}{$\begin{array}{l}\text { Halal Food Supply } \\
\text { Chain }\end{array}$} & + & 4 & 1 \\
\hline & - & 18 & 1 \\
\hline Place & + & 18 & 1 \\
\hline Country of Origin & + & 1 & 1 \\
\hline $\begin{array}{l}\text { Consumer } \\
\text { Segmentation }\end{array}$ & + & 34 & 1 \\
\hline $\begin{array}{l}\text { Customer } \\
\text { Perception }\end{array}$ & + & 11,19 & 2 \\
\hline Loyalty & + & 32 & 1 \\
\hline \multirow[t]{2}{*}{ Quality } & + & 3,32 & 2 \\
\hline & - & 2 & 1 \\
\hline Shariah Compliance & - & 14 & 1 \\
\hline
\end{tabular}




\begin{tabular}{llll}
\hline Determinants & Directions & Studies & $\begin{array}{c}\text { Total Number of } \\
\text { Studies }\end{array}$ \\
\hline Continuance & Table & Determinants affecting halal purchase intention \\
\hline Accessibility & + & 40 & 1 \\
\hline Availability & + & 40 & 1 \\
\hline Marketing Concept & + & 44 & 1 \\
\hline $\begin{array}{l}\text { Advertisement } \\
\text { contains }\end{array}$ & & & 1 \\
\hline - Honesty & + & 23 & 1 \\
\hline -Sexism & + & 23 & 1 \\
\hline - Racism & + & 23 & 1 \\
\hline -Language & + & 23 & 1 \\
\hline -Intention & + & 23 & 2 \\
\hline Health & + & 8,32 & 1 \\
\hline Need of cognition & - & 39 & 1 \\
\hline Advertisement & + & 5 & 1 \\
\hline
\end{tabular}

These variables or determinants are divided into two different categories: internal and external factors. The internal factors include variables that are specific to the individual decision. In contrast, the external factors include variables that define the other circumstances in which the respective customer decides.

\section{Internal factors}

Internal factors category includes variables related explicitly to a particular decision-maker. These variables are generally the result of personal life experiences (attitudes, values, personality, etc.) and affect the individual's decision-making process. This paper includes the following variables.

\section{Attitude}

Table 5 shows that attitude is the most used factor in the studies of consumer purchase intention towards halal products, including food, meat, pharmaceutical, finance, and cosmetics. It is followed by perceived behaviour control. The number of studies using attitude as their halal purchase intention was 21 papers. However, two studies found that attitude does not correlate with the purchase intention of halal products. Generally, it can be concluded that attitude has a positive relation to halal products purchase intention.

\section{Perceived behaviour control}

Table 5 shows that perceived behaviour control is an important factor in halal products' purchase intention. The number of studies using perceived behaviour control is 15 articles. Even though two articles stated that perceived behavior control is not supported in Halal products' purchase intention, overall, it still can be said that these factors have positive and direct effects on consumer halal purchase intentions.

\section{Religiosity}

Religious people tend to apply religious rules and practices without question (Zakaria et al., 2018). The rise in religiosity relates positively and substantially to the intention of the customers to buy halal products. As shown in Tables 4, fourteen studies reported a positive and direct impact of halal products' purchase intentions; however, only one study mentions that religiosity is unrelated to purchase intention. Therefore, it can be deduced that religiosity plays an essential role for the consumer in their purchase intention of Halal products. 


\section{Halal awareness/halal consciousness}

Awareness on Halal or consciousness of Halal was one of the commonly studied variables; eleven papers examined Halal awareness (Table 4). The above findings suggest that Halal awareness has a positive impact on Halal product purchase intention.

\section{Trust}

Trust is characterized as a belief or expectation in the performance of such products. Of the 44 studies analyzed by the authors, five papers tested the role of trust in Halal purchase intention. All these studies have shown that trust positively influences the customer's purchase intention.

\section{Halal knowledge}

Halal knowledge is one of the variables studied in the purchase intention of Halal products. Two papers explored Halal knowledge's roles in consumers' intention to buy halal products (Table 4). Both showed a positive direction, indicating halal knowledge affects the purchase intention of halal products.

\section{Other internal factors}

There other internal factors related to Halal-related purchase intention that is not commonly studied. These factors are loyalty, exposure, self-efficacy, self-identity, moral obligation, motivation, and cognition. All these factors have positive directions to purchase intention towards halal products.

\section{External factors}

These factors represent an external force which affects the intention of consumers to purchase Halal products or services. These forces either encourage or discourage consumers from deciding to buy Halal products. These variables are explained below.

\section{Subjective norm/social norm or reference groups}

About 18 studies explored the effect of the subjective norm/social norm on Halal products' purchasing intention. The result showed 13 papers found that social norms had a positive relationship with the purchase intention. In contrast, five studies found that the subjective norm had a negative relationship with purchase intention. Pradana et al. (2020) conducted a study in Spain and found that subjective norm has a significant impact on Spain's purchasing intention. The impact on Halal purchase intention may be stronger if Muslims are more interested in religious activities in their communities. Moreover, two studies examined word of mouth, and the result found that word of mouth has a positive impact on the consumer in their intention of buying halal products. To sum up, it can be assumed that arbitrary or social expectations and reference groups have mixed relationships with the consumer's Halal purchase intention.

\section{Halal logo / halal certification}

Halal logo/halal certification tells customers about the product's halal characteristics. Halal's description can be labelled on edible products, foods, cosmetics, personal care products, food raw materials, or any food and beverage related product (on their package). The Halal logo could build consumer confidence and promote more sustainable purchases. Nine papers were found to have examined these factors, and the result showed that the halal logo had a substantial effect on Halal purchase intention in seven studies. Unfortunately, two papers reported that the halal logo was not related to halal goods' purchase intention.

\section{Brand components}

Some studies assess the role of brand in influencing Halal purchase intention. Brand components considered include brand love, brand image, brand personality, and brand characteristic. As shown in Table 5, seven papers examined studied these determinants with the positive finding; that shown brand components influence Halal products' purchase intention. In contrast, two journal articles found that brand components do not correlate with Halal products' purchase intention. Furthermore, 
one study discussed the relation of Arabic brand name to Halal products' intention, and the results stated that the Arabic name on the brand does not correlate with consumer purchase intention of Halal products.

\section{Product attributes and quality}

Factors included in product attributes in halal products' purchase intention include ingredients, safety, healthiness, and quality. Two papers stated that quality significantly influences the purchase intention of halal products. However, the other two papers found that quality attributes have no relation to halal products' purchasing intention. Furthermore, another two papers discussed safety and ingredients, respectively, and the findings showed that both safety and ingredients positively influenced halal products purchase intention.

\section{Price}

It has been reported in two studies that price positively affects Halal products' purchase intention. One paper, however, found that price does not influence customers' intention to buy Halal products.

\section{Advertisement}

Arbak et al. (2019) uniquely examined the role of advertisement, which includes contents such as honesty, language, sexism, and racism, affecting the purchase intention of halal cosmetics. To attract and retain consumers in Malaysia, marketers must avoid offending consumers by following Islamic advertising ethics. Pool \& Najafabadi (2015) found that advertisement positively influenced halal cosmetic purchase intention. While one paper said beauty blogger has no relation to increasing purchase intention (Putri \& Abdinagoro, 2018). Two papers studied promotional influence, and the result found that promotional influence has a positive influence on halal products' purchase intention. Ustaahmetoğlu (2020) in Turkey studied religious massage in halal food advertisement positively impacts purchase intention; in contrast, religious massage in bank loan advertisement is significantly not related to purchase intention.

\section{Product availability and accessibility}

Shaari et al. (2020) researched 760 consumers in Malaysia and Thailand in a context related to Halal packaged food items. The study found that in a country with a dominant Muslim population, the demand is more accessible. Whereas in non-Muslim dominant countries, consumers seek availability. In general, both accessibility and availability of Halal packaged food items are crucial for stimulating the purchasing intention.

\section{Other external factors}

There other external factors studied in previous research as well. Fatema et al. (2018), in their research, stated that in Bangladesh, consumers' intention in purchasing Halal finance products does not influence by Shariah compliance. One article studied another factor such as country of origin, Halal supply chain, place, and marketing concept that positively affects Halal product purchase intention. Bhatti et al. (2020) found consumer segmentation has a positive impact on the purchase intention of halal meat in Norway.

\section{DISCUSSION}

Numerous factors affecting customer Halal purchase intention have been identified through a systematic literature review. All of these variables have been found to either promote or discourage the purchasing of halal items. Except for a few studies, multiple studies have found that attitude, subjective norms, perceived behavioral control (also the TPB components), religiosity, Halal awareness, and halal certification/halal logo are the significant factors that influence halal products' purchasing intention.

A previous study mainly found that attitude was a significant factor in shaping Muslim consumers' intention to purchase Halal products. Those with more optimistic attitudes are more likely to have greater intentions to purchase Halal products. In general, these findings indicate that Muslims are aware 
of, and have a reliable, positive attitude towards Halal products that positively influence their intention to purchase these products. The analyses suggested a mainly positive association between perceived behavioural and subjective norms with Muslim consumers' intention to buy Halal products or services. Such findings can be interpreted to indicate that Muslims are more likely to make considerable efforts to obtain halal products. Their subjective norm from their families, friends, and relatives emerged as essential drivers of buying intention. All individuals have different social groups; some social groups may have some "norms" on Halal consumption.

Various literature refers to religiosity as one of the essential influential factors affecting the purchasing of Halal goods. Rasha (2016) strongly argued that Islamic religiosity, health literacy, and faith in Halal food products are the key determinants influencing Muslim consumers' purchase intention on Halal food products. Varinli, Erdem, \& Avcılar (2016) have indicated that consumers' preference for Halal- certified products depends on their religiosity level. Religious people tend to apply religious rules and practices unconditionally. As such, the high religiosity relates positively and substantially to the customers' intention to buy Halal products.

Halal awareness is a common factor chosen by the researcher to test their Halal-related purchase intention hypothesis. Previous studies had gathered evidence that Halal awareness affects consumers' intention to buy halal products. The more consumers know about the Halal concept, the more they know the need to purchase Halal products. The halal logo or certificate is also a common factor tested. The Halal logo has become a keyword and plays an increasingly important role in global markets. It is proven that many studies showed that the Halal logo has a direct positive impact on purchase intention towards Halal products.

Unfortunately, there are limited studies to analyze other determinants such as price, place, brand components, advertising, the marketing concept, halal supply chain, etc. Given the limited number of studies conducted, the relationship between some of the factors towards halal products' intention could not be concluded. The researchers must conduct further studies to analyze the significant of these determinants.

\section{CONCLUSION}

\section{Implications, limitations and directions for future research}

The present research is the first to review articles of determinants affecting purchase intention towards Halal products in a few countries. This research's findings may contribute to understanding the factors that influence halal products and services' purchase intention. Numerous factors encourage or impede the intention to purchase halal products. Factors such as attitude, subjective norms, perceived behavioural control (also the TPB components), religiosity, Halal awareness, and Halal certification/halal logo are significant in Halal purchase intention. Other factors could be significant in improving the purchase intention. However, to determine the position of these factors and the degree to which they influence Halal products purchase intention, further research is required.

This study's results may provide insights into the creation of literature and be valuable to scholars by giving insight into existing factors affecting Halal purchase intention. Another possible research area is applying other purchase intention theories, such as theory consumption value or theory diffusion of innovation in the future. As the demand for Halal lifestyle globally has been increasing every year, more studies can be done in other relatively under-explored fields in the future, such as halal pharmaceutical, Halal fashion, Halal tourism, Halal supply chain, Halal finance. It is recommended for future review studies to adopt more databases to be explored.

Market researchers in general and foreign brands could use this knowledge to plan for their marketing strategies. Producers and retailers will do well to integrate this study's marketing strategies to attract more customers and persuade them to purchase their goods. The government can use this knowledge to improve consumers' purchase rates on Halal products, which may facilitate their local Halal market growth.

\section{ACKNOWLEDGMENT}

The researchers would like to take the opportunity to thank the International Institute for Halal Research and Training (INHART) International Islamic University Malaysia, the Halal Centre 
University of Airlangga for the chance to publish this paper, and all those who had helped and contributed in accomplishing this paper.

\section{REFERENCES}

Abu-Hussin, M. F., Johari, F., Hehsan, A., \& Mohd Nawawi, M. S. A. Bin. (2017). Halal Purchase Intention Among the Singaporean Muslim Minority. Journal of Food Products Marketing, 23(7), 769-782. https://doi.org/10.1080/10454446.2016.1141139

Adura Mohd Yusoff, F., Nerina Raja Yusof, R., \& Rahayu Hussin, S. (2015). Halal Food Supply Chain Knowledge and Purchase Intention. International Journal of Economics and Management, 9(S), 155-172.

Afzaal Ali, Gua Xiaoling, Mehkar Sherwani, A. A. (2017). Factors affecting Halal meat purchase intention - evidence from international Muslim students in China. British Food Journal, 119(3). https://doi.org/10.1108/eb011680

Ajzen, I. (1991). The theory of planned behavior. Organizational Behavior and Human Decision Processes, 50(2), 179-211. https://doi.org/10.1016/0749-5978(91)90020-T

Ajzen, I. (2011). The theory of planned behaviour: Reactions and reflections. In Psychology and Health. https://doi.org/10.1080/08870446.2011.613995

Ajzen, I. (2012). The theory of planned behavior. Handbook of Theories of Social Psychology: Volume 1, 211, 438-459. https://doi.org/10.4135/9781446249215.n22

Ali, Adnan, Ali, A., Xiaoling, G., Sherwani, M., \& Hussain, S. (2018). Expanding the theory of planned behaviour to predict Chinese Muslims halal meat purchase intention. British Food Journal, 120(1), 2-17. https://doi.org/10.1108/BFJ-05-2017-0278

Ali, Afzaal, Ali, A., \& Sherwani, M. (2017). Shaping Halal Into a Brand? Factors Affecting Consumers' Halal Brand Purchase Intention. Journal of International Food and Agribusiness Marketing, 29(3), 234-259. https://doi.org/10.1080/08974438.2017.1312657

Ali, Afzaal, Sherwani, M., Ali, A., Ali, Z., \& Sherwani, M. (2020). Investigating the antecedents of halal brand product purchase intention: an empirical investigation. Journal of Islamic Marketing. https://doi.org/10.1108/JIMA-03-2019-0063

Ali, Afzaal, Xiaoling, G., Sherwani, M., \& Ali, A. (2018). Antecedents of Consumers' Halal Brand Purchase Intention: an Integrated Approach. Management Decision, 56(4), 715-735. https://doi.org/10.1108/MD-11-2016-0785

Arbak, S., Islam, R., \& Rasyid, H. Al. (2019). Relationship Between Advertisement and Purchase On Halal Cosmetic Products In Malaysia. Humanities and Social Sciences Review, 7(3), 683-694.

Arifani, V. M., \& Haryanto, H. (2018). Purchase intention: Implementation theory of planned behavior (Study on reusable shopping bags in Solo City, Indonesia). IOP Conference Series: Earth and Environmental Science, 200(1), 0-6. https://doi.org/10.1088/17551315/200/1/012019

Aslinda Jamil, Atifah Fakhriyah, S. A. R. (2020). A Study on Consumer Purchase Intention towards Halal Cosmetics and Personal Care Products in Selangor, Malaysian. International Journal of Pharmaceutical Research, 13(1), 11-12.

Azam, A. (2016). An empirical study on non-Muslim's packaged halal food manufacturers: Saudi Arabian consumers' purchase intention. Journal of Islamic Marketing, 7(4), 441-460. https://doi.org/10.1108/JIMA-12-2014-0084

Aziz, Y. A., \& Chok, N. V. (2013). The Role of Halal Awareness, Halal Certification, and Marketing Components in Determining Halal Purchase Intention Among Non-Muslims in Malaysia: A Structural Equation Modeling Approach. Journal of International Food and Agribusiness Marketing, 25(1), 1-23. https://doi.org/10.1080/08974438.2013.723997

Bashir, Abdalla M., Bayat, A., Olutuase, S. O., \& Abdul Latiff, Z. A. (2019). Factors affecting consumers' intention towards purchasing halal food in South Africa: a structural equation modelling. Journal of Food Products Marketing, 25(1), 26-48. https://doi.org/10.1080/10454446.2018.1452813

Bashir, Abdalla Mohamed. (2019). Effect of halal awareness, halal logo and attitude on foreign consumers' purchase intention. British Food Journal, 1-18. https://doi.org/10.1108/BFJ-012019- 0011

Bhatti, M. A., Godfrey, S. S., Ip, R. H. L., Gaarder, M. Ø., Aslam, S., Steinheim, G., Wynn, P., Hopkins, D. L., Horneland, R., Eik, L. O., \& Ådnøy, T. (2020). An exploratory study of Muslim consumers' halal meat purchasing intentions in Norway. Acta Agriculturae Scandinavica A: Animal Sciences, O(0), 1-10. https://doi.org/10.1080/09064702.2020.1842488

Bray, J. (2000). Consumer Behaviour Theory: Approaches and Models. 46(1), 2-33. 
https://doi.org/10.1177/002076400004600104

Bukhari, S. N. Z., Isa, S. M., \& Yen Nee, G. (2020). Halal vaccination purchase intention: A comparative study between Muslim consumers in Malaysia and Pakistan. Journal of Islamic Marketing. https://doi.org/10.1108/JIMA-10-2019-0209

Don, P. A. K., Cassidy, J., \& Noor, N. (2016). Factors affecting halal food purchasing by nonMuslims in a multicultural society: a case study in Singapore. International Journal of Islamic Marketing and Branding, 1(4), 366. https://doi.org/10.1504/ijimb.2016.10002301

Elseidi, R. I. (2018). Determinants of halal purchasing intentions: evidences from UK. Journal of Islamic Marketing. https://doi.org/10.1108/JIMA-02-2016-0013

Fatema, M., Islam, M. A., \& Bakar, R. (2018). Halal purchase intention- a study on islamic banks of Bangladesh. Journal of Social Sciences Research, 4(12), 402-412. https://doi.org/10.32861/jssr.412.402.412

Garg, P., \& Joshi, R. (2018). Purchase intention of "Halal" brands in India: the mediating effect of attitude. Journal of Islamic Marketing, 9(3), 683-694. https://doi.org/10.1108/JIMA-11-20170125

Haleem, A., Khan, M. I., Khan, S., \& Jami, A. R. (2020). Research status in Halal: a review and bibliometric analysis. Modern Supply Chain Research and Applications, 2(1), 23-41. https://doi.org/10.1108/MSCRA-06-2019-0014

Hamzah, M. I., Othman, A. K., Rashid, W. E. W., \& Ngah, N. M. A. (2020). The Relationship Between Halal factors and Purchase Intention of Food Products as Moderated by Word-ofMouth Communications. International Journal of Business and Society, 21(2), 865-882.

Haque, A., Sarwar, A., Yasmin, F., Tarofder, A. K., \& Hossain, M. A. (2015). Non-muslim consumers' perception toward purchasing halal food products in malaysia. Journal of Islamic Marketing, 6(1), 133-147. https://doi.org/10.1108/JIMA-04-2014-0033

Hassan, S. H., Mat Saad, N., Masron, T. A., \& Ali, S. I. (2020). Buy Muslim-made first - does halal consciousness affect Muslims' intention to purchase? Journal of Islamic Marketing. https://doi.org/10.1108/JIMA-05-2019-0102

Hussin, S. R., Hashim, H., Yusof, R. N., \& Alias, N. N. (2013). Relationship between product factors, advertising, and purchase intention of Halal cosmetic. Pertanika Journal of Social Science and Humanities, 21(SPEC. ISSUE), 85-100.

Hussin, Siti Rahayu. (2013). Relationship between Product Factors, Advertising, and Purchase Intention of Halal Cosmetic Some of the authors of this publication are also working on these related projects: A case project on SME in Malaysia: Hanizah Optometry View project. Pertanika

J. Soc. Sci. \& Hum, 21, 85-100. https://www.researchgate.net/publication/276160302

ICV. (2019). What is Halal? A Guide for Muslims One Islam - Many Muslims Though Halal is a term designating any object or an action which is permissible to use or engage in , according to Islamic law. It is the opposite of haraam. The term is used to designate food. Islamic Council of Victoria. https://www.icv.org.au/about/about-islam-overview/what-is-halal-a-guide-for-nonmuslims/

Joshi, Y., \& Rahman, Z. (2015). Factors Affecting Green Purchase Behaviour and Future Research Directions. In International Strategic Management Review (Vol. 3, Issues 1-2). Holy Spirit University of Kaslik. https://doi.org/10.1016/j.ism.2015.04.001

Khalek, A. A. (2014). Young Consumers' Attitude towards Halal Food Outlets and JAKIM's Halal Certification in Malaysia. Procedia - Social and Behavioral Sciences, 121(September 2012), 26- 34. https://doi.org/10.1016/j.sbspro.2014.01.1105

Khan, A., Azam, M. K., \& Arafat, M. Y. (2019). Does religiosity really matter in purchase intention of Halal certified packaged food products? A survey of Indian muslims consumers. Pertanika Journal of Social Sciences and Humanities, 27(4), 2383-2400.

Khan, N., Sarwar, A., \& Tan, B. C. (2020). Determinants of purchase intention of halal cosmetic products among Generation Y consumers. Journal of Islamic Marketing. https://doi.org/10.1108/JIMA-11-2019-0248

Kim, H. Y., Chung, J. E., Kim, H. Y., \& Chung, J. (2011). Consumer purchase intention for organic personal care products. Journal of Consumer Marketing, 28(1), 40-47. https://doi.org/10.1108/07363761111101930

Marmaya, N. H., Zakaria, Z., \& Mohd Desa, M. N. (2019). Gen Y consumers' intention to purchase halal food in Malaysia: a PLS-SEM approach. Journal of Islamic Marketing, 10(3), 1003-1014. https://doi.org/10.1108/JIMA-08-2018-0136

Memon, Y. J., Azhar, S. M., Haque, R., \& Bhutto, N. A. (2019). Religiosity as a moderator between theory of planned behavior and halal purchase intention. Journal of Islamic Marketing, 11(6), 
1821-1836. https://doi.org/10.1108/JIMA-01-2019-0006

Mohd Suki, N., \& Abang Salleh, A. S. (2018). Mediating effect of Halal Image on Muslim Consumers' Intention to Patronize Retail Stores: Some insights from Malaysia. Journal of Islamic Marketing, 9(2), 338-355. https://doi.org/10.1108/JIMA-02-2017-0014

Muhamed, A. A., Rahman, M. N. A., Hamzah, F. M., \& Zain, C. R. C. (2017). An investigation towards consumer intention to purchase halal financing product and services using theory of planned behaviour. Advanced Science Letters, 23(9), 8280-8285. https://doi.org/10.1166/asl.2017.9877

Nur Famiza, A., Nor Samsinar, K., Kursimah, H., \& Radin Firdaus, R. B. (2017). Buying Halal Pharmaceutical Products: Do Consumers Have Imperfect Knowledge? Pertanika Journal of Social Sciences and Humanities, 25(December), 153-163.

Nurhayati, T., \& Hendar, H. (2019). Personal intrinsic religiosity and product knowledge on halal product purchase intention Role of halal product awareness. Journal of Islamic Marketing, 11(3). https://doi.org/10.1108/JIMA-11-2018-0220

Nurzulain, Z., Zuraini, M. I., Norhidayah, A., \& Muhammad Afiq, M. (2019). Psychometric evaluation of purchase intention and actual purchase behaviour towards Halal bakery products using rasch analysis. Malaysian Applied Biology, 48(2), 9-15.

Pasha, S., Wahab, S. N., \& Daud, D. (2019). Purchase Intention Towards Islamic Branding. ACM International Conference Proceeding Series, 37-41. https://doi.org/10.1145/3361785.3361808

Paul, J., Modi, A., \& Patel, J. (2016). Predicting green product consumption using theory of planned behavior and reasoned action. Journal of Retailing and Consumer Services, 29, 123-134. https://doi.org/10.1016/j.jretconser.2015.11.006

Pool, J. K., \& Najafabadi, A. H. J. (2015). Developing a Model to Analyse The Effects of Brand Constructs on Word-of-Mouth and Purchase Intention for Halal Brands. Journal for Global Business Advancement, 8(3), 342-353. https://doi.org/10.1504/JGBA.2015.071334

Population, M. (2020). World Muslim Population. Muslimpopulation.Com. http://www.muslimpopulation.com/World/Pradana, M., Huertas-García, R., \& Marimon, F. (2020). Purchase intention of halal food products in Spain: The moderating effect of religious involvement. International Food Research Journal, 27(4), 735-744.

Pradana, Mahir, Huertas-García, R., \& Marimon, F. (2020a). Muslim tourists' purchase intention of halal food in Spain. Current Issues in Tourism, $0(0)$, 1-5. https://doi.org/10.1080/13683500.2020.1797647

Pradana, Mahir, Huertas-García, R., \& Marimon, F. (2020b). Spanish muslims' halal food purchase intention. International Food and Agribusiness Management Review, 23(2), 189-202. https://doi.org/10.22434/IFAMR2019.0200

Pradana, Mahir, Syarifuddin, S., Hafid, H., Gilang, A., \& Diandri, M. (2019). Purchase Intention Determinants of Halal Food in Secular Countries. International Journal of Supply Chain Management, 8(4), 83-89.

Pradana, Mahir, Wardhana, A., Rubiyanti, N., Syahputra, S., \& Utami, D. G. (2020). Halal food purchase intention of Muslim students in Spain: testing the moderating effect of need-forcognition. Journal of Islamic Marketing. https://doi.org/10.1108/JIMA-05-2020-0122

Putri, T. U., \& Abdinagoro, S. B. (2018). Response to a New Wave in Digital marketing: Does beauty blogger involvement the most influencing factor in halal cosmetic purchase intention. International Journal of Supply Chain Management, 7(6), 446-452.

Rachbini, W. (2018). The relationship of attitude, subjective norm, perceived behavioral control on Halal Food Purchasing Behavior in Jakarta. Journal of Business and Management, 20(1). https://doi.org/10.9790/487X-2002030110

Rasha H.A, R. I. E. (2016). Antecedents of UK Muslim's Community Purchasing Behaviour of. LCBR European Marketing Conference, 7, 1-16.

Said, M., Hassan, F., \& Musa, R. (2011). Empirical Study on The Influence of Country-of-Origin on Consumers' Perception Towards Their Purchase Intention of Malaysia's Halal food Products. 2011 IEEE Colloquium on Humanities, Science and Engineering, CHUSER 2011, Chuser 2011, 865-870. https://doi.org/10.1109/CHUSER.2011.6163860

Shaari, H., Ahmad, N., Md. Salleh, S., Mohd Mokhtar, S. S., Yusoff, R. Z., Khamwon, A., \& Putatchote, N. (2020). Does halal product availability and accessibility enhanced halal awareness and intention to purchase halal packaged food products: Malaysia and Thailand's halal industry perspective. International Journal of Supply Chain Management, 9(1), 921-930.

Shah Alam, S., \& Mohamed Sayuti, N. (2011). Applying the Theory of Planned Behavior (TPB) in halal food purchasing. International Journal of Commerce and Management, 21(1), 8-20. https://doi.org/10.1108/10569211111111676 
Shih, Y. (2004). The use of a decomposed theory of planned behavior to study Internet banking in Taiwan. Internet Research, 14(3), 213-223. https://doi.org/10.1108/10662240410542643

Soon, J. M., \& Wallace, C. (2017). Application of Theory of Planned Behaviour in Purchasing Intention and Consumption of Halal Food. Nutrition and Food Science, 47(5), 635-647. https://doi.org/10.1108/NFS-03-2017-0059

Suparno, C. (2020). Online purchase intention of halal cosmetics: S-O-R framework application. Journal of Islamic Marketing. https://doi.org/10.1108/JIMA-09-2019-0192

Syukur, M., \& Nimsai, S. (2018). Factors Influencing The Purchase Intention of Halal Packaged Food in Thailand. International Journal of Supply Chain Management, 7(4), 1-6.

Thomson Reuters, D. S. (2020). State of the Global Islamic Economy Report 2020/21. In Dinar Standard. https://haladinar.io/hdn/doc/report2018.pdf

Ustaahmetoğlu, E. (2020). The influence of different advertisement messages and levels of religiosity on attitude and purchase intention. International Journal of Islamic and Middle Eastern Finance and Management, 13(2), 339-356. https://doi.org/10.1108/IMEFM-02-20190064

Varinli, I.., Erdem, E., \& Avcılar, M. Y. (2016). Exploring the Factors Affecting Purchase Intention of Halal Certified Foods in Turkey: A PLS-Path Modeling Study. In European Journal of Business and Management www.iiste.org ISSN (Vol. 8, Issue 4). Online. www.iiste.org

Ya, S., Nor, M. M. N., Noor, S. M., \& Ahmad, Z. (2017). Purchase intention of Islamic Brand Product Among Non-Muslim Customers. Pertanika Journal of Social Sciences and Humanities, 25(December), 101-109.

Zakaria, Z., Abdul Majid, M. D., Ahmad, Z., Jusoh, Z., \& Zakaria, N. Z. (2018). Influence of Halal certification on customers' purchase intention. Journal of Fundamental and Applied Sciences. https://doi.org/10.4314/jfas.v9i5s.55 